\title{
Liberal Democratic Representation and the Politicization of Religion
}

\author{
Astrid Mattes
}

Political representation, as key concept of liberal democracy, is under multiple pressures. Across many liberal democracies, populist parties, who claim to have a mandate for more direct representation, are on the rise. In their rhetoric, religion plays a crucial role. Religion is, however, not only relevant on a discursive level but in fact involved in all dimensions of political representation and their crises. I deploy Hanna F. Pitkin's concept of representation together with Michael Saward's concept of discursive representation and discuss examples from empirical research on the politicization of religion in Austria in the context of migration. This case is of particular interest when discussing the crisis of representation, as political representation in contemporary Austria is characterized by a strong populist far right party and a recent renunciation of a longstanding inclusive tradition towards politics of religion. I conclude by discussing empirical analyses that show strong exclusionary tendencies towards Muslims while representatives freuquently claim to act as, and speak for, Christians against the increasing pressure on liberalism.

Liberal Democracy; Political Representation; Religious Diversity; Politicization of Religion; Austrian Politics

Astrid Mattes is a postdoctoral researcher at the Institute for Urban and Regional Studies at the Austrian Academy of Sciences with a research focus on the intersections of politics and religion. She studied Political Science and Comparative Religious Studies at the Universities of Vienna and Limerick (Ireland). Previously she worked as a postdoctoral researcher at the research platform "Religion and Transformation in Contemporary Society" and held a predoctoral position at the department of Political Science at the University of Vienna. There she also completed her Doctoral Thesis on the roles of religion in immigrant integration policies. Her main fields of interest are the governing of diversity in liberal democracies, migration and integration politics, religious pluralism and Islam in Europe.

\section{Introduction}

Papers about politics and religion all too often start with a reference to the return of religion to the public sphere or a similar observation. The fact that social scientists are eager to write about politics and religion confirms and reinforces this development. When talking about religion and representation, this is no exception. Within the liberal democratic setting that coined most European states in 
their more recent history, religion played a minor role in the sphere of formal politics. A variety of developments, among them the diversification of religious landscapes, the prominence of religious fundamentalism and religiously motivated violence, growing public resentments against some religious groups, and the (re-)discovery of religion as a resource for voter mobilization, brought religion high on the political agenda.

This politicization of religion happens while political representation, as a central concept of democracy, is under multiple pressures. The crisis of representation, which is debated in this issue, relates to religion in a variety of ways, but as neither religion, nor representation, are enclosed concepts, it is a complex task to pin them down. On the one hand, liberal democratic representation aims to include and mirror societal diversification, also with regards to religion. On the other, religion and the claim for religious representation are used in rhetoric to prevent this inclusion. What is more, the inner diversity of religions makes an apparently simple category of difference difficult to represent and the neutrality mandate of the liberal state prevents state actors from taking sides, at least in theory.

In this paper, I want to ask how religion relates to the idealistic concept of liberal democratic representation and its inherent pitfalls, and which underlying problems of liberal democratic representation are understood with the help of the case of politicized religion. The paper proceeds as follows: First, I will present concepts of political representation, in particular the political system centered approach by Hanna F. Pitkin and Michael Saward's idea of discursive representation. This conceptual introduction will be followed by a discussion of the pitfalls of liberal democratic representation in times of diversifying societies. In a third part, I discuss religion and the crisis of representation, using the Austrian example as a particularly information-rich case, suited for purposeful sampling (Patton 1999). In this third part, I will introduce the case of political representation in Austria, present the empirical data base and discuss the particular role of religion along the empirical results and the theoretical concepts of Pitkin and Saward. In a concluding discussion, I argue that the current crisis of political representation is first and foremost a crisis of liberalism and therefore a question of competing norms.

\section{Conceptualizing Liberal Democratic Political Representation}

When talking about a crisis of liberal democratic representation, it is useful to distinguish the three concepts involved. Representation and its theorization predate democratic systems. Although representation is nowadays mostly discussed in democratic settings, it is in itself not bound to democracy. Thomas Hobbes as one of the most influential thinkers of political representation argued his Leviathan not at all in a democratic perspective, but it is still discussed by 
scholars of representation (Hobbes 1651; Runciman 2010). Democracy, most basically understood as a political system whose members exercise power collectively, can hardly be thought of without any form of political representation. Usually, voting is the mechanism to install "a necessary correspondence between acts of governance and the equally weighted felt interests of citizens with regard to these acts" (Saward 1998,1). Such voting also takes place in a mere issue oriented direct democratic setting. In reality, even political systems with well-developed direct democratic instruments are representative democracies, as they install representatives to govern beyond referenda. Political systems that are further characterized by the acceptance of human rights, the rule of law and its emphasis on the individual as holder of rights and the normative goal of striving towards equality among, and freedom for, their members can be considered liberal democracies (Kelly 2005). Representation in liberal democracies and its proclaimed crisis is this papers' focus.

One of the most well-known scholars in this debate is Hanna F. Pitkin, who calls representation "the making present in some sense of something which is nevertheless not present literally or in fact" $(1967,8)$. This approach to representation is rooted in formerly religious references that have increasingly been understood as political. In a democracy, the something that is not present is the sovereignty of the people, meaning the shared power of the members of the democratic entity, which is not embodied or personalized. Classical questions that theories of political representation consider in this process are what makes a person or institution and their actions representative and for whom or what (individuals, groups, interests, etc.).

Following Hannah F. Pitkin, we can differentiate between formalistic, standing-for (descriptive and symbolic) and substantive representation ${ }^{1}$. Formalistic representation refers to authorization and accountability of representation. While authorization is central to any form of representation, it is not a distinct process. Not every authorized person acts as a representative, which makes authorization a necessary condition but not an exclusive marker for representation. Even non-democratic representation requires authorization. Pitkin points out that Hobbes' concept of representation can be understood as an authorization concept, but remains essentially anti-democratic as once authorized, a representative cannot be held accountable (Pitkin 1967; Runciman 2009, 16). For political representation to function democratically, representatives must be accountable for their acts. Through the possibility of sanctioning, responsiveness is formally established.

Descriptive representation looks at the extent to which representatives mirror the characteristics of their representees (a term used by Pettit 2009) and usually

1 Other authors discuss representation along the lines of simulative, enactive, interpretive representation (Pettit 2010); standing, acting and speaking for someone (Shapiro et al. 2009); For an excellent overview of different concepts see Dovi 2017. 
refers to categories of difference, such as gender, age, ethnicity, language, skin color, sexual orientation, class, etc. Accuracy of resemblance is the ideal of descriptive representation. Jane Mansbridge describes descriptive representation as representation by representatives who are "in their own persons and lives in some sense typical of the larger class of persons whom they represent" $(1999,629)$. Thereby she wants to point out that descriptive representation is not necessarily limited to outward criteria but also involves shared experiences, like a certain profession. For federal political systems, regional representation is usually also an important descriptive issue. Particularly in feminist theories of representation, the issue of descriptive likeliness received great attention. The presence of women in representative functions is a long standing claim (Campbell, Childs, and Lovenduski 2010); one that has been extended to minorities and marginalized societal groups.

Pitkin discusses symbolic representation a second aspect of "standing for" representation. She describes it as the meaning representees ascribe to the representatives. Whether a representee identifies with a representative because they share features or for any other symbolic ascription is irrelevant, as symbolic representation happens on the level of emotions (Stokke and Selboe 2009, 59). This aspect relates to non-formalistic ways of authorization. As representees are not involved in acts of representation, their non-objection functions as some kind of presence in absence, as David Runciman argues $(2009,94)$. Ascribed meaning and the acceptance related to it is then a crucial element to stabilize the process of representation.

Substantive representation refers to actions of representatives and the extent to which they serve the interests of the represented. Such interest representation is then the most straight-forward aspect of representation. Pitkin assumes, in a rather essentialist manner, the presence of social groups within society whose interests can be fed into the political process. This involves a general responsiveness to group needs as well as the according voting behavior. Interests, in Pitkin's view, are relatively stable and given, something that can be picked up for the purpose of representation.

There is an ongoing debate on how standing-for and substantive representation relate. Older social scientific studies have already shown that female representatives do not necessarily act according what is understood as women's interests (Diamond 1977). Clearly, female representatives are not necessarily feminist representatives. In fact, not only mediating factors, such as party political logics and institutional norms, might prevent them from doing so, but differing political attitudes can be a reason for female representatives not to act in what is identified as the substantive interests of women (Celis and Childs 2012). Still, scholars like Iris Marion Young (Young 2002), Jane Mansbridge (Mansbridge 1999) and Michelle L. Swers (Swers 2002) have demonstrated how descriptive representation of women has effects beyond the most direct aspect of "acting for", namely raising responsiveness to women's interest on a more general level, and 
most importantly the inclusion of women into the circle of those perceived as able to rule.

Pitkin's work is still a useful starting point when thinking about representation. Her differentiation of aspects of representation is a well-structured approach, useful to analyze different facets of political representation. There is, however, severe criticism concerning the accuracy of approaches to representation that focus closely on the political system and its institutions and understand representation as a principal agent relationship (Severs and Dovi 2018, 309). Pitkin's essentialist view on both groups and interests is definitely outdated.

Following the cultural turn in social sciences, groups are rather understood in the sense of 'imagined communities' than as bounded entities (Anderson 1991). Equally, a more complex understanding of political processes includes the making of both interests and groups in the course of representation, rather than their given presence (Celis and Childs 2012). The performative act of representation constitutes and constructs political realities (Diehl 2015, 10). Such discursive views understand representation as "a 'practice' in which the object of representation and the grounds on which it is defended, co-determine 'who' and 'what' is considered politically legitimate and how 'interests' are to be represented" (Crivits et al. 2018, 475).

As much as Pitkin's work is central to political system centered approaches to representation, Michael Saward's work is central to the scholarly debate about discursive representation. In his book "The representative claim", Saward put forward a constructivist understanding in studying representation and suggests focusing on discursive representation and claims-making instead of investigating representation as a principal agent relationship (2010). His arguments also strongly built on the disability of political system focused approaches to grasp power relations and the (non-)representation of marginalized groups, non-state centered, international forms of representations and dynamics of representation. In short, Saward and scholars of discursive representation increasingly try to avoid the shortcomings of 'standard accounts of democratic representation' (Urbinati and Warren 2008) by perceiving discursive acts, defined as claims, as representation.

This way of thinking denies theorists the possibility to identify what the interests of representees are and, in consequence the assessment of their representation. Only the perception of representees with regard to representative acts can be assessed. In this perspective, also representatives are not concerned with making claims according to women's or worker's interests but aim at making claims that resonate among their voters. The conditions in which these claims are made are then the focus in analyzing discursive representation.

Despite a heavy reception, Michael Saward's "representative claim" is considered as a dead end by some scholars. The constructivist perspective does not allow the identification of interests and thereby questions every concept of democratic representation and, in consequence, the possibility of democratic 
politics itself (Disch 2015). Such contrasting of a political system orientation and a discursive approach is hardly fruitful. Rather, I suggest combining these ways of thinking to enhance the standard perspective on political representation. Saward himself points out "that democratic representation contains, but is not exhausted by, the familiar machinery of liberal representative democracy" $(2012,78)$. And, although national political systems have lost power to corporations, civil society and supra-national political actors, they are far from being irrelevant.

A combination of both perspectives is useful when we look at the different aspects of representation and their crises. Therefore, I will stick to Pitkin's concept in structuring this article but include a wider understanding of representation than that as a principal agent-relationship. Informed by the constructivist perspective on groups and interest, I analyze the crisis of representation along standard procedures of political representation in a liberal democratic setting.

\section{Problems of Liberal Democratic Representation}

If we ask for the crisis of political representation, we find pressing issues for each of the aspects of representation described by Hanna Pitkin that relate inherently to the concept of representation, triggered by recent societal transformation processes. While these transformations are not the only possible way in which the concept of political representation might be challenged, their current dense constellation leads to a perception of crisis.

\section{a) Formal Representation}

Regarding formal representation, elections as an institution to grant both authorization and accountability is delegitimized by a growing gap between those who are involved in decision making and those that are affected. This boundary problem (Dahl 2000; Goodin 2007; Gruber and Walter 2013) is both the result of increasing numbers of residents who are not citizens and shrinking voting rates due to decreasing interest in "mainstream representative politics" (Saward 2010, 1) on the nation state level. ${ }^{2}$ Here lies the first currently pressing problem of the concept of liberal democratic political representation, as formal representation in a liberal democracy strives for widest inclusion to grant equality. Those affected by representative acts should be involved in authorization processes and be able to hold representatives accountable.

As David Runciman discusses, this accountability is crucial to the very concept of representation, as the represented become somewhat present only through their ability to object: "Representation implies that the represented do not merely bear the consequences of another's action, but have some presence in the action

2 Authorization and accountability are also a challenge on a global scale, as currently most evident in climate politics (see for example Caney 2005). 
itself by dint of this fact. In other words, they must be capable of asserting their stake." $(2007,96)$ This is not the case when significant parts of the population are excluded from both aspects of formal representation or refuse to participate.

The question of how the electorate is constituted and who is actually (not) voting has become ever more pressing over the past years. The number of residents who are not entitled to vote is rising due to migration movements and small naturalization numbers, which results in a crisis of representation (see Bauböck and Carens 2018). For Austria, the share of foreign citizens grew from 8.6 percent in 1999 to 15.3 percent in $2017,{ }^{3}$ and similar trends are observable across Western Europe. In cities, these numbers are usually higher and in particularly diverse areas, those entitled to vote are only a thin majority. In the Austrian capital Vienna, the share of foreign citizens is on average 25 percent and as high as 42.8 percent in some districts (Rudolfsheim-Fünfhaus) ${ }^{4}$.

Another aspect that limits representativeness in a formalistic sense is citizens who do not exercise their right to vote. As they are not formally excluded from participation, falling turnouts are also a matter of symbolic representation and will be discussed below. From the perspective of formal representation, both the exclusion of larger shares of the population and the refusal to participate are not foreseen and limit the legitimacy of liberal democratic political representation.

\section{b) Descriptive Representation}

Descriptive representation is a challenged concept as migration processes and changing perceptions of difference result in ongoing diversification both in width and in depth. In the debate over descriptive representation, scholars distinguish microcosmic and selective approaches. While the former aims at an exact mirroring of the total population and can only be achieved through lottery, the latter is the reality of liberal democratic representation. "In the far more frequent 'selective' form of descriptive representation, institutional design gives selected groups greater descriptive representation than they would achieve in existing electoral systems in order to bring the proportions of those groups in the legislature closer to their percentages in the population." (Mansbridge 1999, 633). For most parts of Europe, current informal section criteria result in an over-representation of males, the highly educated, white people and a certain age group.

Despite the growing acceptance for the representation of some group characteristics, there is little reason for enthusiasm. Descriptive representation follows larger societal trends regarding the perception and acceptance of diversity. For example, changing societal stands (as well as significant court rulings) on diversity allow for more visibility of some groups (especially women and LGBTQ people, see Reynolds 2013; Wängnerud 2009). Although women's voting rights are well established by now, Cuba (49 percent), Bolivia (51 percent) and Rwanda (63

3 See derstandard.at (2017), "Ein Viertel der Bewohner Wiens darf nicht wählen".

4 See ORF.at (2017), "Jeder vierte Wiener nicht wahlberechtigt". 
percent) are the only countries in the world that reach a representation of women in parliament that matches the population (data.worldbank.org). Regarding other forms of diversity, especially concerning markers of difference that relate to migration, it seems acceptance for descriptive representation remains low.

As Iris Marion Young pointed out, the descriptive likeliness of representatives is crucial for democratic inclusion but any group inclusion bears the danger of excluding another $(2002,87 \mathrm{f}$.). Which marker of difference is the most important to be mirrored in political representation? Gender, religion, age, region, language, class? And when, if at all, can we assume common interests of woman, homosexuals, Protestant Christians, best agers, Tyrolianys, Carinthian Slovenes, construction workers? The vast literature on "groupism", "imagined communities" and intersectionality discusses the multiple ways in which descriptive representation therefore clearly has limits (Gold and Haynie 2014; Brubaker 2002; McCall 2005).

This further relates to a crucial point for the following discussion of liberal democratic representation: Descriptive likeliness relates to group characteristics and thereby group representation. The liberal democratic concept by contrast, puts the individual at the center of political representation, which brings along the challenge of weighing individual and group interests. Some individuals will experience inequality due to group membership, whether or not these groups are imagined or ascribed. Also to guarantee freedom might require acknowledging group needs, as the examples of religious freedom and the non-discrimination on the grounds of sexual orientation show. Ignoring groups therefore undermines the liberal goals of equality and freedom. Governing groups by contrast always limits the fundamental liberal democratic focus on the individual as bearer of equal rights.

The inherent dilemma of descriptive representation can then be subsumed as the most likely permanent inability to mirror societal diversity in its fluidity and multitude, while at the same time, such mirroring is needed to prevent exclusion. Growing numbers of characteristics people claim representation for, as well as a refusal to allow for the representation of some characteristics, results in a virulent problem and contribute to the current crisis of representation.

\section{c) Symbolic Representation}

The symbolic view on representation looks at the meaning people ascribe to their representatives. Here, we simultaneously observe a growing disaffection from formal politics and the increasing success of politicians of populist and authoritarian style who push for a symbolic charging of the nation (Beyme 2018). Both developments are symptoms of a crisis of representation.

Identification with political parties that where formative for many post-war European democracies has been declining for decades now. In many cases, political parties used to have an all-encompassing agenda for their partygoers' life courses (Andeweg and Farrell 2017). While these parties are still most relevant to 
the formal political system, the dissociation of voters and mainstream parties is growing and results in low turnouts. This is further pushed by dissatisfaction with these established actors. Scholars name a series of reasons for this dissatisfaction, reaching from economic insecurity in a post-industrial economy to powerlessness of political actors in the light of technocracy, supra-national governance and allmighty corporations, and a cultural backlash in a retro reaction to societal value change (Inglehart and Norris 2016; Cox 2018; Torre 2014).

Such manifold transformation processes allowed populist parties to step in and gain significant success by claiming to speak "for the people", used synonymously for the claim to represent more immediate than mainstream parties. Populist actors are then often perceived as an alternative to the established system of political parties. Populist rhetoric is charged with symbolic references aimed at the stimulation of emotions. Mobilizing fear, nostalgia and a romanticized vision of the nation characterizes the successful strategies of right-wing populists across Europe. While their claims are not necessarily anti-democratic, they usually turn against the liberal ideals of freedom and equality.

Populists' claim to speak for the people is increasingly accepted as a valid claim, and their agenda is adopted by mainstream parties (Bale et al. 2010; Gruber and Bale 2014), resulting in mainstream and right-wing actors who push an illiberal agenda. In fact, as Fielitz and Laloire argue, "illiberal models of democracy", such as in Poland and Hungary, prove populist actors' "capacity to transform entire political systems" $(2016,15)$. It can be reasonably assumed that this relates directly to the crisis of symbolic representation: Dissociation of established party structures, anti-establishment attitudes, political discontent are symptoms of the diminishing meaning a growing number of people no longer ascribe to mainstream political representatives.

As Runciman argues, representees' non objection is required to allow their presence in absence in processes of representation. A diminishing ascribed symbolic meaning results in an objection that limits this presence. In this case, liberal democratic representation foresees to hold representatives accountable and replace them. The current challenging of representation by actors that actually oppose the liberal foundation of contemporary democracies makes evident that this system of representation is unable to protect itself against its abolition (as famously discussed by Böckenförde 1976).

\section{d) Substantive Representation}

Substantive representation is expressed in the prioritization of policy preferences of the represented. Here, Michael Saward's thinking is crucial, as he argues that we cannot simply assume interests are taken for granted. He states that a claim is not merely representing the interests of those represented but that representativeness depends on the extent to which a claim is accepted as being representative and resonates among the represented. 
What political analysists often overlook is that the interests looked at might not be quite accurate. For example, being female might not be the group identity that a person develops her interests upon. As a study on female Trump voters shows, holding sexist and racist attitudes was more influential to women in their decision to vote for Trump than what is understood as gender related interests (Setzler and Yanus 2018). Also, a policy might actually hurt a particular group but is sold to them as being in their interest. Timothy Snyder speaks of "sadopopulists" (2018), when referring to populist actors who make policies against the interest of the people they claim to speak for.

When looking at substantive representation, the critique of Pitkin's approach becomes most evident. Still, the complete dissolution of interests questions democratic representation as such, therefore I view (group) interests as heavily influenced by discourses but not as inexistent. For some time, strong party ties and a greater congruency of societal cleavages and political parties aligned interests, representative's claims and their acceptance. However, as discussed above, these societal structures are increasingly eroding. The concept of democratic representation still builds on these societal structures. Unaligned interests and changing group identifications are a pitfall to the concept of liberal democratic representation and a central element in the crisis of substantive representation.

The crisis of representation then includes formal aspects with regard to authorization and accountability in democratic entities that exclude more and more people from these processes. It further constitutes a limited descriptive representation due to the (ongoing) exclusion of people with certain markers of difference and inability of microcosmic reflection of a growing diversity. In symbolic terms, we observe a dissociation of people and established structures of representation. This relates to the crisis of substantive representation, which results from diverging societal interests and, as revealed by a discursive perspective on representation, a limited ability to understand interests as something given in society instead of something created through representation itself.

\section{Politicized Religion and the Crisis of Representation}

In the course of the ongoing, severe societal transformations described above, religion plays a crucial role in multiple ways. Having described the crisis of political representation in more general terms, I want to discuss recent developments in Austrian politics on religion, against the backdrop of these developments in the following. Therefore I briefly describe the Austrian case and the empirical studies I draw on, followed by a discussion of religion and the crisis of representation in Austria. 


\subsection{Austria: Land of Milk and Honey for Religious and Far Right Populists alike?}

I chose this provocative headline, as Austrian politics is a prominently featured case both in studies on right-wing populism and religious inclusiveness (see for example Kitschelt and McGann 1997; Hainsworth 2016; respectively Foret and Itçaina 2013; Mattes, Goetsch, and Rosenberger 2017). Today, Austria has, despite recent setbacks, a highly inclusive system of state-religion relations and one of the strongest populist far right parties in Europe (Freiheitliche Partei Österreichs, FPÖ), which is, since 2017, also in government. Both relate closely to Austrian history and, in a way, the shirking of dealing with it.

Austria's religious inclusiveness is a relic from the Hapsburg monarchy, when for tactical reason, and maybe as well in the spirit of Enlightenment, rather tolerant legislation allowed for religious diversity (Klieber 2010). After 1945, the Austrian body of law was mostly adopted from the pre-WWII and pre-Austrofascist period. Also, the 1912 Islam Law was still in force when growing religious diversity became an issue in post-war Austria. A group of Muslims founded a Kultusgemeinde in the 1970s, which resulted in a legally acknowledged Islamic Religious Community in Austria that became the official representation for Muslims in Austria (Kroissenbrunner 2002). Until 2013, when an Alevi religious community was granted the same legal status, it served as a single point of contact for state actors.

The inclusiveness of Austrian state religion relation is not limited to an institutional setting that guarantees a broad set of privileges for 16 legally acknowledged religious communities (see Bundeskanzleramt, Kirchen und Religionsgemeinschaften); it also led to inclusive decision making when it came to issues of religious freedom. Examples for this, could be found when the Muslim headscarf was discussed across Europe in the early 2000s (see Rosenberger and Sauer 2013), or in the case of male circumcision (Wieshaider 2016). In these and other cases, coalition governments including the populist far right, as well as grand coalitions of Social Democrats (Sozialdemokratische Partei Österreichs, SPÖ) and People's Party (Österreichische Volkspartei, ÖVP) refrained from restraining religious rights. This tradition of inclusiveness has changed in recent years, in particular with regard to Islam (Hafez and Heinisch 2018). Here, longstanding claims from the far right, such as the ban of face veiling, were recently implemented.

This relates to the second characteristic of the particular information-rich Austrian case, a strong and long-established populist right. Unlike Germany, Austria did not go through a phase of severe examination of its National Socialist past, as it was claimed to be "the first victim" of Nazi-aggression (Rathkolb 2015). This also resulted in the continued existence of a political representation of the, traditionally anti-cleric "third camp"

5 In the interwar period, Austrian politics was split into three camps: socialist, 
(Verband der Unabhängigen) formed as a political gathering place of former National-Socialists and fascists (Pelinka 2002, 286 f.). In 1956, the Austrian Freedom Party (Freiheitliche Partei Österreichs) absorbed this party. Anton Pelinka argues that the FPÖ as a whole stood in the National Socialist tradition. After a liberal phase between 1970 and 1986, Jörg Haider became party leader and the party position shifted to right-wing populism. Since 1986 the Austrian Freedom Party was successful in most elections and gained up to 26 percent of the votes at national elections. A party schism brought the current party leader HeinzChristian Strache, who entered a coalition government with the Austrian People's Party in 2017, to the forefront. Under Strache's lead, the party did not only put anti-Islam campaigns at the center of their political strategy, it also contrasted these with references to Austria's and their own Christian character (Sauer and Ajanovic 2016).

\subsection{Empirical Database and Analysis}

This paper draws on the empirical work from a larger project on the politics of religion and migration in Austria (Mattes 2017a, 2017b, 2018). This project built on four sources of data material: Policy documents on immigrant integration issued in Austria between 2005 and 2013, a formative phase for Austrian immigrant integration policies; Press releases and campaign material in relation to the policy documents were used to complement the picture; Parliamentary protocols allowed the inclusion of data material within a larger period, namely 1993-2013; For this article, the data collection has been further extended to 2017. Finally, qualitative interviews were conducted to bring in policy makers' and religious representatives' voices.

Christian-social, and German-nationalist (Campbell and Gerlich 2000). Also in post-war Austria, the latter is usually referred to as the "third camp". 
Astrid Mattes

\begin{tabular}{|c|c|c|c|}
\hline $\begin{array}{l}\text { Parliamentary } \\
\text { Protocols } \\
\text { (1993-2017) }\end{array}$ & \multicolumn{2}{|l|}{ Policy Documents } & Interviews \\
\hline \multirow{3}{*}{$\begin{array}{l}\text { Number of } \\
\text { documents } \\
\text { analysed: } \\
464\end{array}$} & $\begin{array}{l}\text { - Expert Analysis on } \\
\text { Integration 'Ge- } \\
\text { meinsam kommen wir } \\
\text { zusammen' (2008) }\end{array}$ & \multirow{3}{*}{$\begin{array}{l}\text { Press releases and } \\
\text { campaigns by Minis- } \\
\text { try of Interior }\end{array}$} & \multirow{2}{*}{$\begin{array}{l}\text { INT AT1: } \\
\text { Federal Ministry } \\
\text { for Europe, In- } \\
\text { tegration and For- } \\
\text { eign Affairs } \\
02 / 15 / 15 \text {, Vienna }\end{array}$} \\
\hline & $\begin{array}{l}\text { - Survey 'Integration in } \\
\text { Austria' (2010) }\end{array}$ & & \\
\hline & $\begin{aligned} \text { - National Action Plan } \\
\text { for Integration (2010) }\end{aligned}$ & & \\
\hline \multirow{3}{*}{$\begin{array}{l}\text { Number of } \\
\text { quotations } \\
\text { coded: } \\
839 \\
\text { (in } 126 \text { docu- } \\
\text { ments) }\end{array}$} & $\begin{array}{l}\text { - Work Program Ex- } \\
\text { perts Council for In- } \\
\text { tegration } \\
\text { - Annual Progress Re- } \\
\text { port on the National } \\
\text { Action Plan for In- } \\
\text { tegration }(2011)\end{array}$ & \multirow{3}{*}{$\begin{array}{l}\text { Press releases and } \\
\text { campaigns by State } \\
\text { Secretariat for In- } \\
\text { tegration }\end{array}$} & $\begin{array}{l}\text { INT A2: } \\
\text { Islamic Religious } \\
\text { Community in } \\
\text { Austria } \\
08 / 31 / 16 \text {, Vienna }\end{array}$ \\
\hline & $\begin{array}{l}\text { - Annual Progress Re- } \\
\text { port on the National } \\
\text { Action Plan for In- } \\
\text { tegration (2012) } \\
\text { - } \text { Report on the Dia- } \\
\text { logue Forum Islam }\end{array}$ & & \multirow{2}{*}{$\begin{array}{l}\text { INT AT3: } \\
\text { Archdiocese of } \\
\text { Vienna } \\
\text { 26/09/16 Vienna }\end{array}$} \\
\hline & $\begin{array}{l}\text { - Annual Progress Re- } \\
\text { port on the National } \\
\text { Action Plan for In- } \\
\text { tegration }(2013)\end{array}$ & & \\
\hline
\end{tabular}

Table 1: Overview Data Material

Policy documents were analysed using qualitative content analysis (Hsieh and Shannon 2005). Parliamentary protocols were analysed using a simple version of quantitative content analysis in combination with a qualitative content analysis (Kelle 2004). Interview transcripts were analysed using a 'themed analysis' (Froschauer and Lueger 2003). In the following part of the paper I will, though not exclusively, draw on this study to build and underline my argument. 


\subsection{Religion and the Crisis of Representation in Austria}

The guiding question for this paper is how religion relates to the idealistic concept of liberal democratic representation and its inherent pitfalls, and which underlying problems of liberal democratic representation the case of politicized religion helps to understand. To answer this question I want to look at the current crisis of representation in Austria and the ways religion is involved in it. I start by looking at each aspect of Pitkin's concept of representation and assess religion's general relevance to liberal democratic representation, followed by a discussion of elements of politicizations identified in the empirical analysis of the Austrian case.

\section{a) Formal Representation}

When we look at formal political representation in liberal democracies, religion should simply be irrelevant. Religious affiliation is not only protected by antidiscrimination legislature, freedom of religion is also guaranteed by the commitment to universal human rights and constitutional regulations. In a narrow understanding of formal representation through elections, neither authorization nor accountability can be formally based on religious affiliation or attitudes towards religion.

When we look more closely and apply a slightly wider understanding, we find that religion can be a relevant factor on a formal level of representation, and in fact for both representees and representatives. Unlike the liberal democratic ideal of strict religion-state separation, many European states installed so called "systems of cooperation" that foresaw privileges and duties of acknowledged communities on a constitutional level (Minkenberg 2003). Political scientists like Wayne Hudson (2003), or Julia Mourão Permoser and Sieglinde Rosenberger for Austria (2009) argue that within a concept of multiple citizenships (national, local, EUropean, global, etc.), what they call "religious citizenship" is often overlooked. While this "religious citizenship" is not a legal status like nationality, membership in a religious community can open windows of opportunity through group representation, also in formal terms.

For Austria, Mourão Permoser and Rosenberger argue, that due to the Austrian system of cooperative state-religion relations, religious membership is in fact a benefit for non-citizens. People might be entitled to vote for a religious representative (e.g. in the legally acknowledged Islamic and Jewish Communities), despite not being entitled to vote for state representatives. While migrants in general do not have an official representative channel, they might have one through their religious affiliation. The system of cooperation between state and legally acknowledged religious communities foresees consultation of religious organizations for all matters of religion politics, and, to a lesser extent, also in other legislative procedures. "Religious citizenship" entails both a legal form of representation and a more general discursive one. This is especially relevant for 
religious communities that have large shares of migrant members, such as the Islamic community and Christian-Orthodox churches.

On the other side, there is a utilization of religious communities to implement immigrant integration policies, treating them as representatives of migrants, rather than as religious actors. As discussed by various authors, religious communities and Islamic communities in particular, become subject of the practice of governing through community (Tezcan 2012; Ragazzi 2016). While for some time in the early 2000s and especially through a multiculturalism lens, these practices have been assessed as inclusive, the specific politicization of Islam and Muslims, as well as growing resentments among the public and policy makers alike, lead to the assessment that such representation is barely able to lead towards more legitimate authorization or wider accountability (Mattes 2017a). As an interviewee from the Islamic Religious Community in Austria put it: "Even in my official function I encounter people who really have a hard time digesting that it is possible to be Muslim and Austrian. Islam is something out of Austria, tolerated in a guest status, at best." (AT2, 04:08)

As it bears the danger of further exclusion I do not view a stronger involvement of religious communities as a solution for better formal representation of religious migrants. The selective process of acknowledging religious communities only considers a very specific sub-group of religiously affiliated people and therefore cannot function as a way to include foreign citizens. Rather, an individual involvement through the acquisition of citizenship is desirable to improve liberal democratic representation. There are no official numbers of religious affiliations among migrants and naturalizations. Looking at the most politicized example of religious migrants, Muslims in Austria, it is estimated that around 50 percent of the 700000 Muslims living in the country hold Austrian citizenship (Hager and Peternel 2018). ${ }^{6}$

Obviously, naturalized members of religious minorities are entitled to participate in elections, which means that representatives are accountable to them. However, even if religious minorities are involved in representation processes, a minority position in democratic election only allows for limited influence. There are various concepts and reform ideas to improve minority representation, reaching from affirmative action to quotas, but all of them bear the danger to undermine the liberal focus on the individual. In fact, representative democracy is conceptualized to avoid the "tyranny of the masses", as representatives are supposed to act in the democratic interest of minority representation. In light of the current politicization of religion - Christianity and Islam as markers for self- and otherness - the extent to which representatives fulfill this task is questionable.

6 There are no estimations of the share of Austrian citizens among the 500000 orthodox Christians and around 15000 Jews living in Austria (Goujon, Jurasszovich, and Potančoková 2017). 
Therefore, religious representation is hardly suitable to address the formal problem of the growing number of non-represented.

\section{b) Descriptive Representation}

Descriptive representation is, as argued by Young, a potential source for democratic representation that aims towards justice $(2002,82)$. But to what extent is religion relevant for descriptive representation? As religion is a typical category of difference, it is regularly discussed with regards to descriptive representation. Young differentiates between cultural and structural differences and would, in the first place, view religion as a cultural difference, as opposed to a structural one like gender, sexual orientation and race. For Europe, scholarly literature increasingly assesses a racialization of religion and Islam in particular. As Fatima El-Tayeb argues, in a European context where race is a historic societal taboo, veiled Muslim women become the visible other to the essentially white European self (El-Tayeb 2011, 16).

In addition to whether difference is cultural or structural, we can look at the perception and presentation of difference. While many members of Austrian parliament are religiously affiliated, very few make their religious position explicit. Assessing the composition of the Austrian National Assembly in the XXVI legislative period (which began in 2017 and does not significantly differ from former periods), four among the five members with a migration background have roots in Muslim-majority regions (Draxler and Schaffer 2017). None of them presents him/herself as a devout believer or claims to stand for Muslims in Austria. Some explicitly see themselves as secular or not practicing Muslims (Pink 2008; Rajkovic 2017); another Muslim parliamentarian explicitly states his skepticism about the relation of religion and politics in general (Dönmez 2017). There are two Jewish members of parliament, one of them claims to be the first "active Jew" in post-war Austrian Parliament (kurier.at 2017). With regard to different Christian representatives, one way to assess their presence is the affiliation of MPs with Christian organizations (see webpage Meine Abgeordneten) but only few Christian parliamentarians proactively communicate their religious affiliation.

Findings from the "Giving Voice Project" that investigated descriptive representation in Austrian parliament show that religion, mingled with the label "immigrant background", is a double edged sword. While religious affiliation is increasingly pointed out among male candidates of Turkish origin, other candidates (especially Muslim women who do not wear a headscarf) are perceived and addressed as religious candidates to a lesser extent (Rosenberger and Stöckl 2016). Instead of standing for Muslims in Austria, these candidates aimed to be perceived as party representatives. Even if political actors of a particular faith would want to stand for the religious community, it would be unclear whose religion they represent, as spectrums of religiosity reach from secular affiliation to active practice and devout dedication. Descriptive religious representation, then, is 
limited to single representatives, who explicitly claim standing for very specific groups.

Rather than looking at descriptive likeliness in relation to substantive interest representation, we can assess the relevance of the presence of minority characteristics among representatives parallel to Michelle L. Swers findings on women's representation (2002): Presence of especially marginalized religious people is crucial to raise the responsiveness to minority interest on a more general level, and can include these marginalized people into the circle of those perceived as able to rule.

\section{c) Symbolic Representation}

The relevance of religion for symbolic representation relates closely to the problem of diverse groups and homogenous labels. According to Pitkin's concept, symbolic representation considers the role of "irrational belief" and "the importance of pleasing one's constituency" $(1967,111)$. Descriptive likeliness might occur, but representation also requires the represented to view the representatives as standing for them. In recent years, religion played an increasing role in both the "irrational beliefs" of voters and the attempts to please them by representatives.

According to surveys, the share of people who view Austria as a "Christian country" is high, at about 76 \% (IMAS 2016,3). Recent numbers from a study on Christians in Western Europe show that while 80 percent view themselves as Christian, only 30 percent go to church from time to time or regularly (Pew Research Center 2018). 39 percent even stated that one needs to be Christian to be "one of us" (ibid.). Christian religious representation then seems to be not so much about descriptive likeliness but about symbolic representation and the "irrational belief" related to it.

The politicization of religious symbols functions as a prime example. In many European states, among them Austria, full-face veiling has been legally banned. Despite minimal numbers of women wearing this particular clothing, the measure has been argued to be integrative and necessary to stop "counter-society" (Marchart 2016). In the course of the same legal brief, religious symbols for magistrates in court were to be dismissed ${ }^{7}$, but the government representatives immediately stressed, that this would not concern the crucifixes, which are installed in Austrian court rooms. Despite rapidly shrinking numbers of practicing Christians in Austria, the crucifix in public places like courts and schools has been heatedly debated and representatives mostly favor or refrain from opposing their presence. Current Vice-Chancellor Heinz-Christian Strache, from the far right and-populist Austrian Freedom Party, famously held a speech against "Islamization", holding a crucifix in his hand and publicly talked about his Catholic confirmation at the age of 39 (derstandard.at 2009). Here, religion becomes a

7 In the end, this measure was not introduced by law, but through an executive order. 
symbol to please voters and serve the irrational believe that religion relates to belonging.

Saward's focus on the discursive construction of meaning, and in particular the concept of boundary drawing, helps to assess this symbolic level of representation. Symbolic boundaries are 'conceptual distinctions' that social actors implement to 'separate people into groups and generate feelings of similarity and group membership' (Lamont and Molnár 2002,168) and these examples for the current politicization of religion demonstrate its functioning.

In theory, the usage of religion for symbolic boundary drawing puts liberal democratic actors in a dilemma, as they commit to state neutrality (Madeley 2003). However, drawing on religion for boundary-making is in practice not limited to Austria's far right populist representatives. As shown in other studies on mainstream integration policies, what it means "to be Austrian" is often linked to Christianity, which is presented as the source of liberalism and secularism (Mattes 2017b). An extreme example from an Austrian policy document states:

"The following discussion will show that the problem of integrating foreigners predominantly concerns members of the Islamic culture, to a lesser extent also those of other (for example African or Asian) cultures." (BMI 2008, p. 18)

This statement is followed by a discussion of 'Austrian values', a listing of liberal norms. On the basic principle of equality the document states:

"The principle of equality derives from statements of the Old and especially the New Testament, that all men are equal before God." (BMI 2008, p. 20)

This raises the question to which extent symbolic representation for non-Christians is in possible, if legitimate representation is, in the current climate of politicized religion, discursively linked to a Christian character of representees. The electoral success of those representatives who engage in symbolic boundary drawing on religion allows the assumption that the meaning representees ascribe to representatives is equally dominated by the othering of Islam and Muslims.

\section{d) Substantive Representation}

Substantive representation relates to the contents of political representation, which frequently involve religion in many ways. Above, I discussed the difficulties of unaligned interests for the purpose of representation. As became evident in the discussion of symbolic representation and as frequently discussed by political scientists, identity politics is becoming a societal cleavage along which some political representatives increasingly align themselves (Bale 2017). While it is discussed whether identity conflicts replace economic conflicts or disguise them, their current predominance severely affects substantive representation. The alignment of representatives along cleavages of identity politics also involves a 
repositioning towards liberal democracy. Increasingly, mainstream actors from the center-right engage in the politicization of religion and Islam in particular.

This can be demonstrated when looking at claims about Islam and Muslims in Austrian parliament. When asking who makes claims about Muslims, and what the content of these claims is, results from a long-term study, that investigated Islam in immigrant integration policy debates in the Austrian National Assembly from 1993 onwards, show the processes of alignment along the cleavage of identity politics.

The overall development of average claims made per session (Fig 1) shows an unsteady picture. While in 2001, the year the terror attacks of 9/11 were committed, a small peak is observable, the years that followed did not experience a significant politicization of Islam and Muslims. Only in 2006/2007 much higher numbers of claims made are observable, reaching up to 11 claims per parliamentary session. This 2007 peak was not observed in the following years, when, on average 2-3 claims were made.

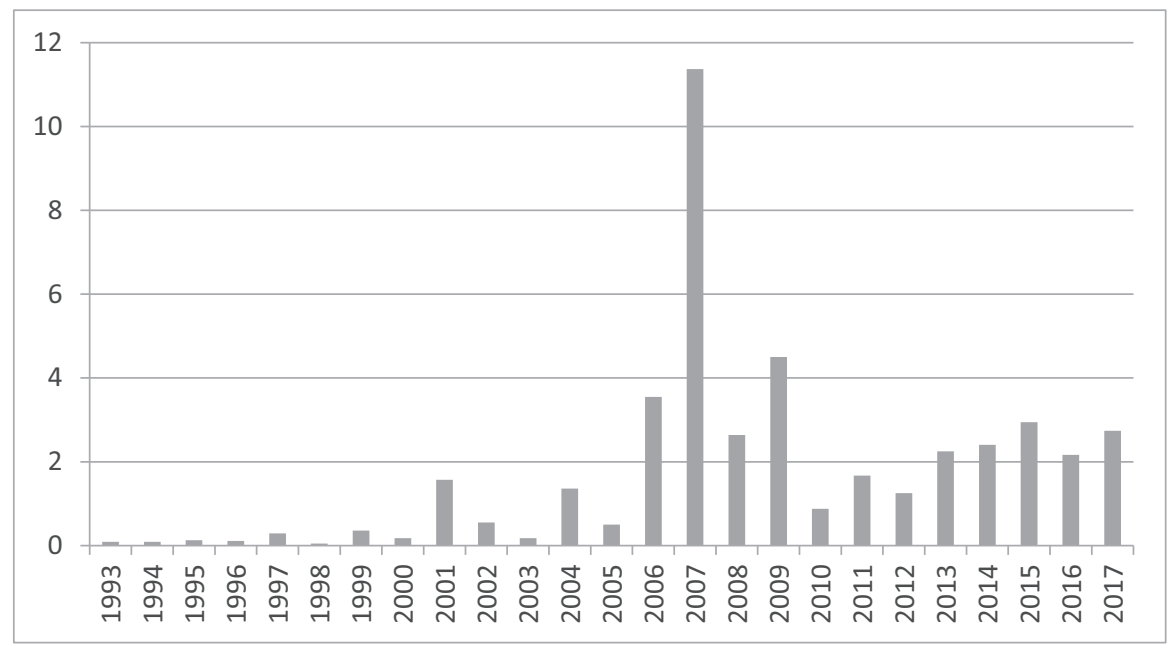

Figure 1: Average claims on Islam/Muslims per debate in Austrian National Assembly (1993-2017)

It is worth splitting up these results with regard to political parties to see which actors make these claims. Between four and six parties held seats in Austrian parliament. The traditionally large mainstream parties are the Social-Democratic Party (SPÖ) and the Christian-democratic People's Party (ÖVP). Since 1986 (until 2017), the Green Party was represented in the National Assembly. The Austrian Freedom Party (FPÖ) had a split-off party (BZÖ) between 2005 and 2013 with an almost identical position, which was later on absorbed by the FPÖ. Since 2013, there has been a liberal party in parliament (NEOS), and a billion- 
aire's populist short term party project (Team Stronach) was present from 20132017.

In 2001 (Fig. 2), we observe substantive representation of Islam as an issue for niche parties. While the far right pushed the debate about Islam with security claims, the Green party called for diversification. Both "niche parties" on the left and right could have benefited from the politicization of the issue (Gruber 2014).

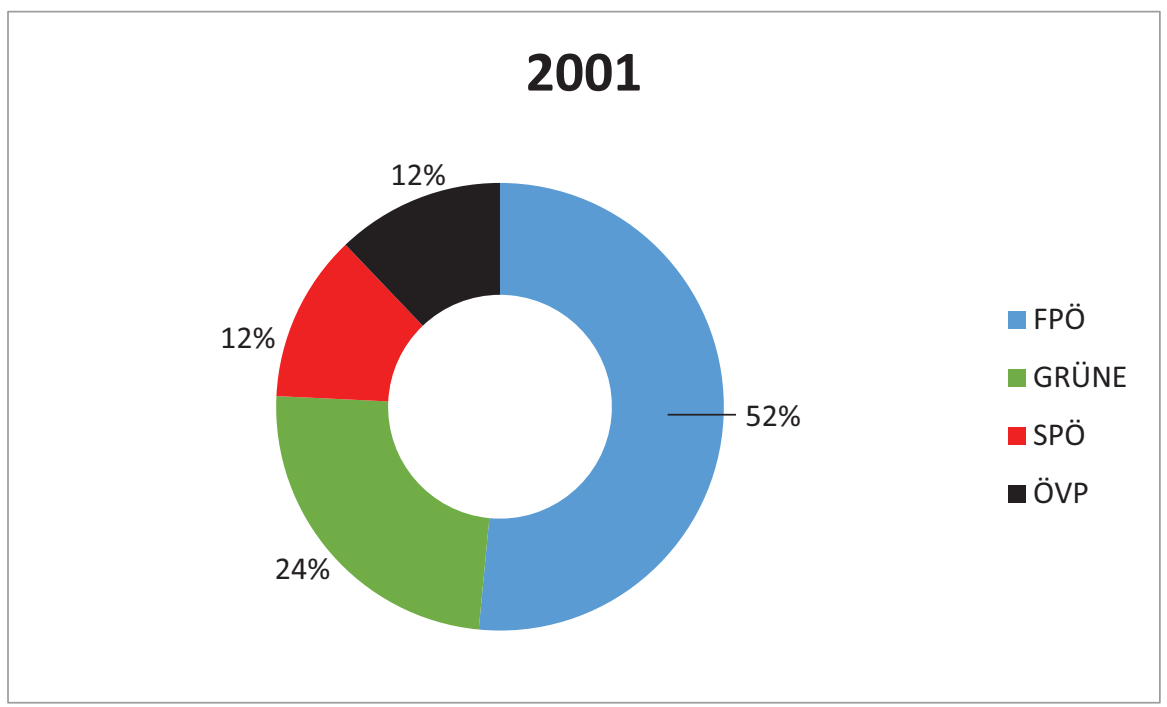

Figure 2: Claims on Islam/Muslims in Austrian National Assembly in 2001 by political party, $n=33$

In 2007 (Fig. 3), when the far right (the Austrian Freedom Party and their split-off BZÖ) decided to put anti-Islam rhetoric at the center of their voter mobilization strategies (Rosenberger and Hadj-Abdou 2013), their share climbed up to 75 percent of the claims of a much higher total (as seen in Fig. 1).

In 2015 (Fig. 4), the populist far right no longer made an absolute majority of claims (33 percent), but the Christian-democratic ÖVP (32 percent) and the liberal NEOS (28 percent) each have a similar sized share. The Austrian SocialDemocratic Party (5 percent) and the Greens (1 percent) hardly made any claims on Islam/Muslims anymore.

Over the years, we see a development from niche, to far right, to mainstream. Politicization started as a niche party phenomenon (2001), was then pushed by the far right (2007) and resulted in politicization throughout the right of the political spectrum (2015).

To provide information on the content of these claims, the data was also coded with regards to the issues addressed. Through inductive category development, six 


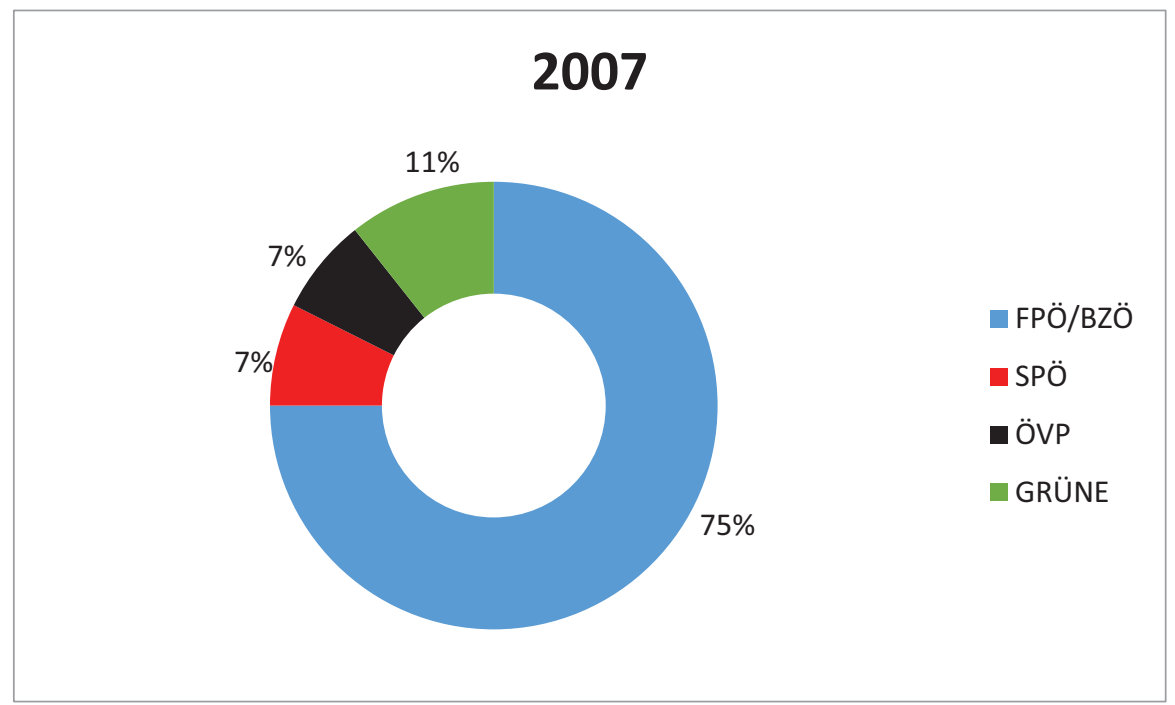

Figure 3: Claims on Islam/Muslims in Austrian National Assembly in 2007 by political party, $\mathrm{n}=216$

\section{5}

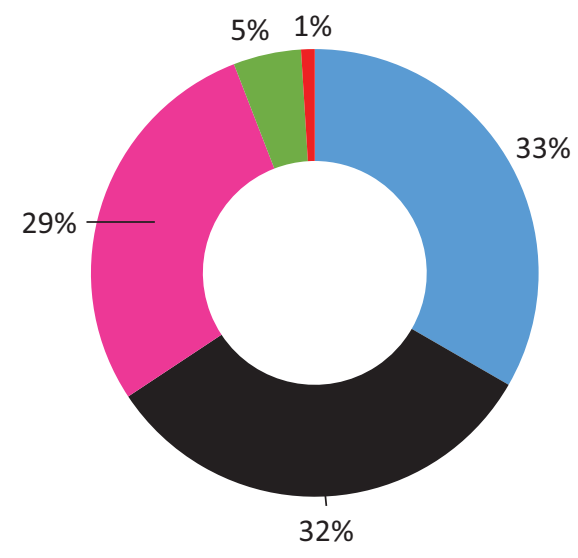

—FPÖ

- ÖVP

NEOS

- GRÜNE

- SPÖ

Figure 4: Claims on Islam/Muslims in Austrian National Assembly in 2015 by political party, $\mathrm{n}=105$ 
issue clusters were identified ${ }^{8}$. If we look at the issues addressed (Fig. 5), we see that populist far right claims (FPÖ/BZÖ) focused on security (36 percent) and values (33 percent), to a lesser extent on establishment issues (then usually directed towards the withdrawal of rights). Overall, the ÖVP made most of their claims on differentiation (26 percent), followed by values (22). 18 percent of the party's claims were made on establishment and dialogue. Social-Democrats made 46 percent of their claims on differentiation, followed by establishment and values (15 percent each). The Green Party focused on differentiation (56 percent) or general issues of integration. Two parties were in parliament only for the last legislative period under observation (2013-2017) and show very different patterns. Team Stronach's claim-making resembles the far right pattern, focusing on security (47 percent) and values (30 percent). The liberal NEOS focused on differentiation (36 percent), establishment (32 percent) and values (18 percent).

If we merge these results (Fig. 6) and look at the overall claims-making, we see distinct patterns. First, the far right (FPÖ and BZÖ) dominated the debate and made, overall, 62 percent of the claims during the 20 year period of observation. All other parties played a much smaller role, they made less claims and if they did, they addressed different issues. The left pushed for differentiation, but in the overall picture, these claims played a minor role.

While the study is not suitable to assess the role of religion for substantive representation as such, the empirical data clearly shows an interest alignment on the right of the political spectrum along the lines of religious identity politics over the past years. Rather than arguing that it is in Christians' interest to claim the exclusion of Islam and Muslims, as the populist far right suggests, we have to deploy Saward's perspective on discursive representation: Interests are never essential; they are not something that is just there, waiting to be picked up by political representatives but something that is both produced and reproduced in the process of representation. The boundary drawing against Muslims is also therefore an interest that is discursively produced, resonates among representees and is again represented by political actors.

Equality might be the liberal goal, but it is inequality that many voters are calling for. Populist actors are willing to represent this call for inequality and, at

8 dialogue: claims about Islam/Muslims related to interreligious dialogue, religious diversity and the coexistence of religions; differentiation: claims about 'Muslims' that condemn generalizations over Muslims, discrimination against Muslims or the anti-Islam mobilization by political parties; establishment: claims on issues on the accommodation of religion, state-religion relations and legal regulation of religious practices are subsumed here; integration: claims about Islam/Muslims related to general notions of immigrant integration, including issues of residence status and participation are summarized; security: claims about Islam/Muslims as a security threat or in relation to terrorist organizations; values: claims about Islam/Muslims in the context of debates about collective identity and common values. 
Astrid Mattes

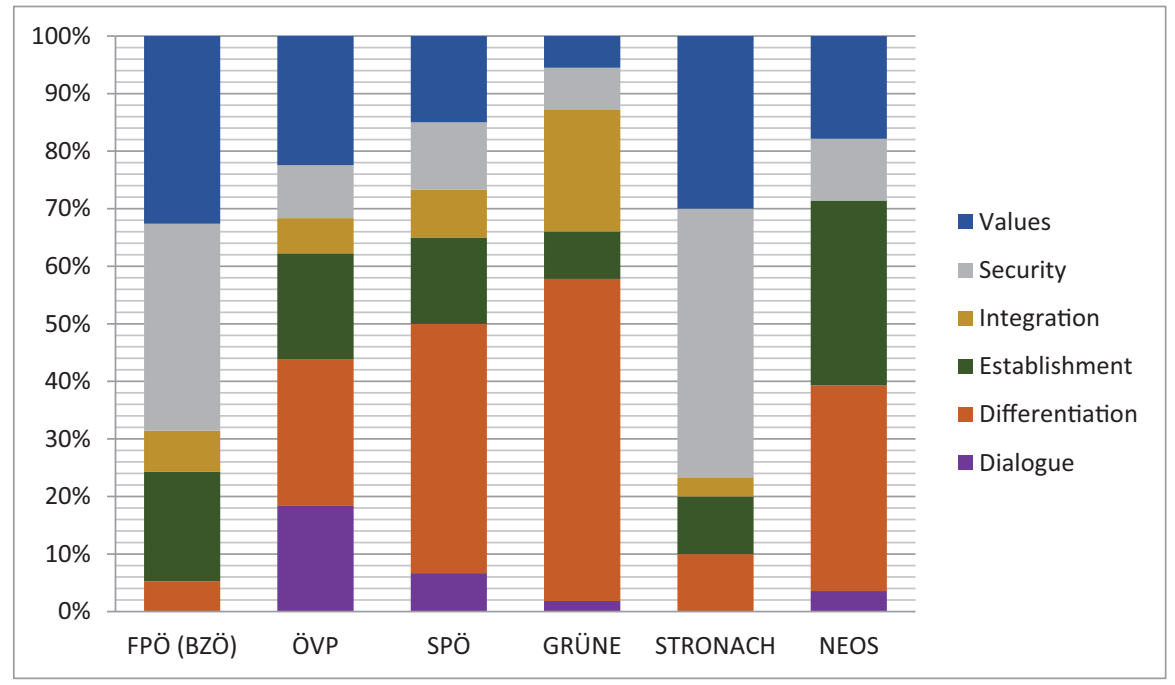

Figure 5: Political parties' claims on Muslims/Islam by contextual issue (1993-2017// 2013-2017)

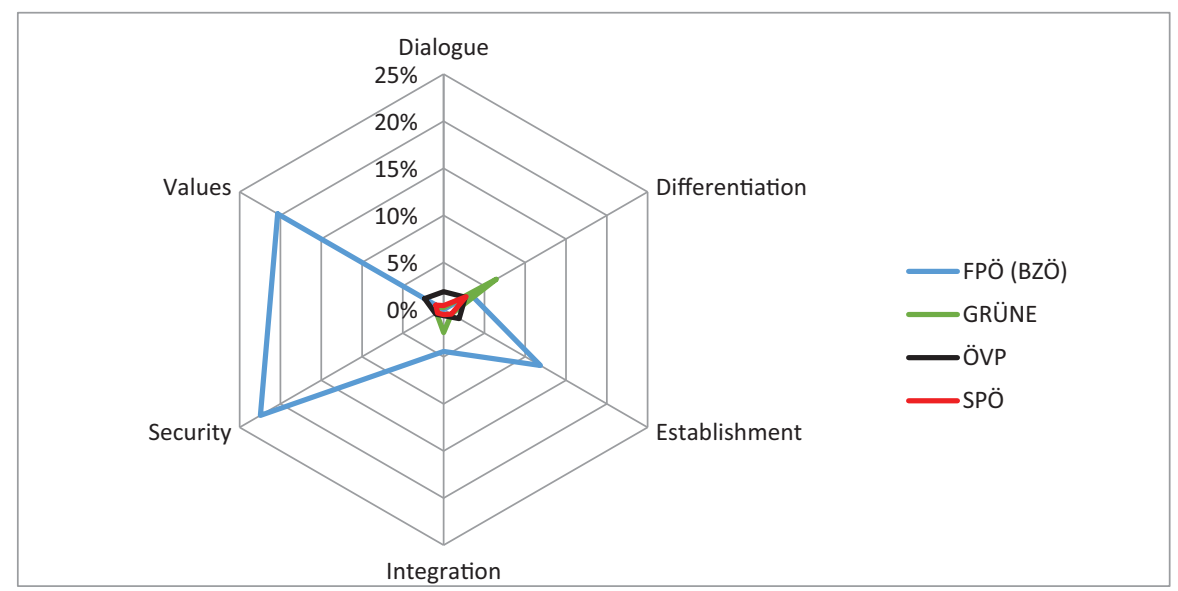

Figure 6: Overall claims on muslims/Islam by contextual issue and political party (19932017)

the same time, promote the exclusionary and often racist ideas behind it. Among representatives of other parties, we observe three strategies: First, some left wing actors might oppose the right-wing populists' argument directly, as the Green party did in the early 2000s. Secondly, they might adopt the right-wing populist's argument, as the ÖVP has done in recent years. Finally, they might refrain from engaging in the debate, as the SPÖ has done in recent years (and to a lesser extent

\section{4}


the Green Party). So far, right-wing populists seem to benefit from each of these strategies, as the first one creates a broader politicization, the second allows for the implementation of measures through coalitions and the third enables the attraction of voters that are concerned by the issue and feel their former representatives are not providing solutions. Together, these strategies result in the alignment of representatives on the right, along an identity politics cleavage.

\section{A Crisis of Liberalism, Not a Crisis of Democracy? Towards a Conclusion}

The above discussion of empirical results shows us that the politicization of (religious) difference is closely related to the current crisis of representation in its different facets. Formal representation depends on participation, which requires both the willingness and the ability of the population to participate in authorization and accountability processes. This is currently challenged by growing numbers of foreign citizens who are not entitled to vote and low turnouts among those who hold citizenship. Religious citizenship, a concept described as bringing privileges to the religiously affiliated, even if they do not hold citizenship, is not a viable alternative as it bears the danger of exceptionalization and exclusion. Descriptive representation is challenged by societal diversification on the one hand, and the questionable essential character of societal groups on the other. The extent, to which descriptive representation is possible, depends on the formation of societal groups and their acceptance among the wider population. The politicization of religion means that representatives who belong to religious minorities are in a difficult situation, as they are asked to stand for a religious community, while at the same time being confronted with a lacking acceptance of their affiliation. Symbolic representation, the meaning ascribed to representatives, also faces the problem of increasingly exclusionary tendencies. Here, religion is among the central elements representatives use to draw symbolic boundaries that resonate among their voters. This relates to substantive representation which is challenged by the dissolving societal cleavages and unaligned interests. The now observable alignment of interests along an identity politics cleavage involves religion and bears the danger to allow for a tyranny of the masses, something liberal democratic representation is supposed to prevent.

Political liberalism names equality and freedom as the basis for a just system and only operates within these limits. In the light of political representation it becomes ever more evident that this principle of equality is under distress. Equal representation for all, by all and of all is questioned not only at the intersection of religion and migration but in more general terms. As Kemmers et al. impressively demonstrate for people with anti-establishment attitudes in the Netherlands, explaining their behavior through deviance or viewing them as "losers of modernity" only works so far. Rather, the qualitative study shows that people con- 
sciously develop such attitudes, which involves "a profound change of their ideas on, and subsequent evaluation of, the workings of politics and society" (2016, 768). As the aforementioned study on female Trump voters shows, holding sexist and racist attitudes was more influential to women in their decision to vote than the gender specific interests they were expected to vote on (Setzler and Yanus 2018).

The unpleasant part for those in favor of liberal democracy, which definitely includes the majority of Europe's political elites, is that the representation made by the populist right and demanded by their voters is not undemocratic, it is just not liberal. Following the logic of political system centered approaches to representation, making these interests present in the political arena is still a democratic act. The constructivist's perspective would add that these interests are equally produced instead of just adopted and might lead to different conclusions. Together, both perspectives allow the assessment of the crisis of political representation, which seems to be, first and foremost, a crisis of competing norms and the turn against liberalism. Yascha Mounk argues that liberalism and democracy do not fit together as naturally as many people, and experts, believe. "The will of the people increasingly goes against the rule of law and dissolve liberal democracy." $(2018,116$ f) While I do not share his perception of the people's will, as I am with Saward's conception of interests, Mounk makes an important point regarding the concepts of liberalism and democracy. The success story of the liberal ideal to maximize freedom and equality goes hand in hand with democratization process in many places. They are however, not inextricably linked.

As I argued in this paper, liberal democratic representation is currently under multiple pressures. It is liberalism that is under attack, as well as the specific form of representation that the normative concept of liberalism demands. Illiberal forms of democracy are possible and in fact currently observable in European states like Hungary and Poland. The question of how to prevent other countries, like Austria, from this development is more than pressing and for sure there are no simple solutions. A de-politicization of religion seems crucial, as liberal democracy's ability to function on group representation is limited. Both equality and freedom are first and foremost norms for the individual. In the politicization of religion, inequality is fostered on the basis of group affiliation. Liberal democracies, therefore, require a juggling act to balance the two. Illiberal actors who are not interested in holding up that balance have an easy game. Some scholars then point at rule of law and the justice system as a security mechanism in liberal democracy. In my view, this is not sufficient. Liberal democracy has to be won discursively through the better argument and claims that resonate. These have to include plausible places for religion in society that allow for the normalization of religious diversity.

9 Translated by the author. 


\section{References}

Andeweg, Rudy / David Farrell: "Legitimacy Decline and Party Decline”, in: van Ham, Carolien / Thomassen, Jacques / Aarts, Kees / Andeweg, Rudy: Myth and Reality of the Legitimacy Crisis: Explaining Trends and Cross-National Differences in Established Democracies, Oxford University Press, Oxford 2017, 76-94.

Bauböck, Rainer / Carens, Joseph H.: "Democratic Inclusion: Rainer Bauböck", in: Dialogue. Critical Powers, Manchester University Press, Manchester 2018.

von Beyme, Klaus von: Rechtspopulismus: Ein Element Der Neodemokratie?, Springer VS, Wiesbaden 2018.

Campbell, David / Gerlich, Peter: "Austria: From Compromise to Authoritarianism”, in: Berg-Schlosser, Dirk / Mitchell, Jeremy: Conditions of Democracy in Europe, 1919-39 Systematic Case Studies, Basingstoke, Macmillan 2000, 40-58.

Dahl, Robert A.: On Democracy, Yale University Press, New Haven 2000.

El-Tayeb, Fatima: European Others: Queering Ethnicity in Postnational Europe, University of Minnesota Press, Minneapolis 2011.

Foret, François / Itçaina, Xabier: Politics of Religion in Western Europe: Modernities in Conflict?, Routledge, New York 2013.

Froschauer, Ulrike / Lueger, Manfred: Das qualitative Interview: Zur Praxis interpretativer Analyse sozialer Systeme, WUV Universitätsverlag, Wien 2003.

Gruber, Oliver: Campaigning in Radical Right Heartland: The Politicization of Immigration and Ethnic Relations in Austrian General Elections 1971-2013, Lit-Verlag, Zürich 2014.

Gruber, Oliver / Walter, Florian: "Politische Inklusion und boundary problem: Aktuelle Herausforderungen und demokratietheoretische Antworten", in: Ataç, Ilker / Rosenberger, Sieglinde: Politik der Inklusion und Exklusion, V\&R unipress, Wien 2013, 72-89.

Hainsworth, Paul: Politics of the Extreme Right: From the Margins to the Mainstream, Bloomsbury Publishing, London / New York 2016.

IMAS: "Religiöses Verhalten in Österreich", Nr. 26/2016. IMAS, Wien 2016.

Kelle, Udo: "Computer Assisted Qualitative Data Analysis", in: Seale, Clive / Gobo, Giampietro / Gubrium, Jaber F. / Silverman, David: Qualitative Research Practice, SAGE, London 2004, 443-59.

Kitschelt, Herbert / McGann, Anthony J.: The Radical Right in Western Europe: A Comparative Analysis, University of Michigan Press, Ann Arbor 1997.

Klieber, Rupert: Jüdische, christliche, muslimische Lebenswelten der Donaumonarchie 1848-1918, Böhlau, Wien 2010.

Kroissenbrunner, Sabine: "Islam in Austria”, in: Hunter, Shireen: Islam, Europe's Second Religion: The New Social, Cultural, and Political Landscape, Greenwood Publishing Group, Westport 2002, 141-55.

Mounk, Yascha: Der Zerfall der Demokratie: Wie der Populismus den Rechtsstaat bedroht, Droemer, München 2018.

Patton, Michael Quinn: "Enhancing the Quality and Credibility of Qualitative Analysis", in: Health Services Research 34 (5 Pt 2): 1189-1208. 
Pelinka, Anton: "Die FPÖ in Der Vergleichenden Parteienforschung: Zur Typologischen Einordnung Der Freiheitlichen Partei Österreichs", in: Österreichische Zeitschrift Für Politikwissenschaft 31, 3/2002: 281-90.

Pettit, Philip: "Varieties of Public Representation", in: Shapiro, Ian / Stokes, Susan C. I Wood, Elisabeth Jean / Kirshner, Alexander S.: Political Representation, Cambridge University Press, New York 2009, 61-89.

Pitkin, Hanna F.: The Concept of Representation, University of California Press, Berkeley / Los Angeles / London 1967.

Rathkolb, Oliver: Die paradoxe Republik: Österreich 1945 bis 2015, Paul Zsolnay Verlag, Wien 2015.

Rosenberger, Sieglinde / Hadj-Abdou, Leila: "Anti-Islamic Mobilisation of the Extreme Right in Austria", in: Godin, Emmanuel / Jenkins, Brian: Varieties of Right-Wing Extremism in Contemporary Europe, Routledge, London 2013, 149-63.

Rosenberger, Sieglinde / Mourão Permoser, Julia: "Religious Citizenship versus Politics of Migrant Integration: The Case of Austria”, in: Bramadat, Paul / Köenig, Matthias: International Migration and the Governance of Religious Diversity, Cambridge University Press, Kingston 2009, 259-292.

Rosenberger, Sieglinde / Sauer, Birgit: Politics, Religion and Gender: Framing and Regulating the Veil, Routledge, London 2013.

Saward, Michael: The Representative Claim, Oxford University Press, New York 2010. Shapiro, Ian / Kirshner, Alexander S. / Stokes, Susan C. / Wood, Elisabeth Jean: "Editors' Introduction" in: Shapiro, Ian / Kirshner, Alexander S. / Wood, Elisabeth Jean / Stokes, Susan C.: Political Representation, Cambridge University Press, New York 2009, 1-15.

Snyder, Timothy: The Road to Unfreedom: Russia, Europe, America, Crown, New York 2018.

Tezcan, Levent: Das muslimische Subjekt: Verfangen im Dialog der Deutschen Islam Konferenz, Konstanz UnivPress, Paderborn 2012.

Young, Iris Marion: Inclusion and Democracy, Oxford University Press, New York 2002.

\section{Internet Sources}

Bale, Tim / Green-Pedersen, Christoffer / Krouwel, Andrea / Luther, Kurt Richard / Sitter, Nick: "If You Can't Beat Them, Join Them? Explaining Social Democratic Responses to the Challenge from the Populist Radical Right in Western Europe", in: Political Studies 58, 3/2009: 410-26, available here: https://doi.org/10.1111/j.14679248.2009.00783.x [downloaded 2010].

Bundeskanzleramt, Kirchen und Religionsgemeinschaften: available here: https://www. bundeskanzleramt.gv.at/kirchen-und-religionsgemeinschaften [September $25^{\text {th }}$, 2018].

Caney, Simon: "Cosmopolitan Justice, Responsibility, and Global Climate Change", in: Leiden Journal of International Law 18, 4/2005: 747-75, available here: https://doi.org/ 10.1017/S0922156505002992 [downloaded 2005].

derstandard.at: "Ein Viertel der Bewohner Wiens darf nicht wählen”, in: der standard.at, available here: https://derstandard.at/2000064028438/Ein-Viertel-der-BewohnerWiens-darf-nicht-waehlen [September $\left.13^{\text {th }}, 2017\right]$. 
Liberal Democratic Representation and the Politicization of Religion

derstandard.at: "Strache in Wr. Neustadt gefirmt", in: derstandard.at, available here: https://derstandard.at/1245820301835/Strache-in-Wr-Neustadt-gefirmt [June 29 $\left.{ }^{\text {th }}, 2009\right]$.

ORF.at (2017): "Jeder vierte Wiener nicht wahlberechtigt", in: ORF online, available her: https://wien.orf.at/news/stories/2871616/ [October 11 $1^{\text {th }}, 2017$ ].

Disch, Lisa: "The 'Constructivist Turn' in Democratic Representation: A Normative Dead-End?", in: Disch, Lisa: Constellations 22, 4/2015: 487-99, available here: https://doi.org/10.1111/1467-8675.12201 [downloaded 2015].

Dönmez, Efgani: “Trennung von Staat und Religion”, in: Efgani dönmez (blog), available here: https://efganidoenmez.at/tag/trennung-von-staat-und-religion/ [September $24^{\text {th }}$, 2017].

Dovi, Suzanne: "Political Representation", in: The Stanford Encyclopedia of Philosophy, available here: https://plato.stanford.edu/archives/win2017/entries/political-representa tion [September $\left.27^{\text {th }}, 2018\right]$.

Draxler, Peter / Schaffer, Tom: "Mehr Christians als Menschen mit Migrationshintergrund", in: Kurier.at, available here: https://kurier.at/politik/inland/nationalratmehr-christians-als-menschen-mit-migrationshintergrund/297.141.794 [November $\left.9^{\text {th }}, 2017\right]$.

Goodin, Robert E.: "Enfranchising All Affected Interests, and Its Alternatives", in: Philosophy \& Public Affairs 35, 1/2007: 40-68, available here: https://doi.org/10.1111/ j.1088-4963.2007.00098.x [downloaded 2007].

Gruber, Oliver / Bale, Tim: "And It's Good Night Vienna. How (Not) to Deal with the Populist Radical Right: The Conservatives, UKIP and Some Lessons from the Heartland", in: British Politics 9/2014, available here: https://doi.org/10.1057/bp.2014. 7 [downloaded 2014].

Hafez, Farid: "Alte Neue Islampolitik in Österreich? Eine Postkoloniale Analyse Der Österreichischen Islampolitik", in: Zeitschrift Für Politik 65, 1/2018: 22-44, available here: https://doi.org/10.5771/0044-3360-2018-1-22 [downloaded 2018].

Hager, Johann / Peternel, Evelyn: "Gehört Der Islam Zu Österreich?”, in: Kurier.at, available here: https://kurier.at/politik/inland/gehoert-der-islam-zu-oesterreich/4000 10799 [March 25 $\left.{ }^{\text {th }}, 2018\right]$.

Hsieh, Hsiu-Fang / Shannon, Sarah E.: "Three Approaches to Qualitative Content Analysis", in: Qualitative Health Research 15, 9/2005: 1277-88, available here: https:// doi.org/10.1177/1049732305276687 [downloaded 2005].

Hudson, Wayne: "Religious Citizenship", in: Australian Journal of Politics and History 49, 3/2003: 425-29, available here: https://doi.org/10.1111/1467-8497.00296 [downloaded 2003].

Kemmers, Roy / van der Waal, Jeroen / Aupers, Stef: "Becoming Politically Discontented: Anti-Establishment Careers of Dutch Nonvoters and PVV Voters", Current Sociology 64, 5/2015: 757-74, available here: https://doi.org/10.1177/ 0011392115609651 [downloaded 2016].

kurier.at.: "ÖVP-Politiker: Antisemitische Bedrohung durch Muslime”, in: Kurier.at, available here: https://kurier.at/politik/inland/oevp-politiker-antisemitische-bedro hung-durch-muslime/302.801.444 [December 19 $\left.{ }^{\text {th }}, 2007\right]$.

Marchart, Jan Michael: "Burka-Verbot ohne Burka", in: Wiener Zeitung Online, available here: https://www.wienerzeitung.at/nachrichten/oesterreich/politik/839239_Bur ka-Verbot-ohne-Burka.html (downloaded on 18.08.2016) [August $18^{\text {th }}, 1016$ ]. 
Mattes, Astrid: "Part of the Problem or of the Solution? The Involvement of Religious Associations in Immigrant Integration Policy", in: Österreichische Zeitschrift für Politikwissenschaft 46, 1/2017: 43-57, available here: https://doi.org/10.15203/ozp.1589. vol46iss1 [downloaded 2017a].

Mattes, Astrid: "Who We Are Is What We Believe? Religion and Collective Identity in Austrian and German Immigrant Integration Policies", Social Inclusion 5, 1/2017: 93 104, available here: https://doi.org/10.17645/si.v5i1.766 [downloaded 2017b].

Mattes, Astrid: "How Religion Came into Play: "Muslim" as a Category of Practice in Immigrant Integration Debates", in: Religion, State and Society 46, 3/2018, available here: https://doi.org/10.1080/09637494.2018.1474031 [downloaded 2018].

Mattes, Astrid / Goetsch, Katharina / Rosenberger, Sieglinde: "Restoring Routine by Debating Tolerance? Discursive Responses to Jihadist Terrorist Attacks", Politics, Religion \& Ideology 18, 3/2017: 264-281, available here: https://doi.org/10.1080/21567 689.2017.1351955 [downloaded 2017].

Meine Abgeordneten, available here: https://www.meineabgeordneten.at/ [September $\left.25^{\text {th }}, 2018\right]$

Pettit, Philip N.: "Representation, Responsive and Indicative", in: SSRN Scholarly Paper ID 2699304, Rochester, NY, Social Science Research Network, available here: https:// papers.ssrn.com/abstract $=2699304$ [downloaded 2010].

Pew Research Center: "Being Christian in Western Europe", Washington DC, available here: http://assets.pewresearch.org/wp-content/uploads/sites/11/2018/05/14165352/ Being-Christian-in-Western-Europe-FOR-WEB1.pdf [downloaded 2018].

Pink, Oliver: "Muna Duzdar: Die palästinensische Parlamentarierin", in: Die Presse, available here: https://diepresse.com/home/politik/neuwahlen/411666/Muna-Duzdar _Die-palaestinensische-Parlamentarierin [September $4^{\text {th }}, 2008$ ].

Ragazzi, Francesco: "Suspect Community or Suspect Category? The Impact of Counter-Terrorism as 'Policed Multiculturalism'". Journal of Ethnic and Migration Studies 42, 5/2016: 724-41, available here: https://doi.org/10.1080/1369183X.2015. 1121807 [downloaded 2016].

Rajkovic, Amar: "Ich würde meinen Sohn Nicht Mohammed nennen." Das Biber, available here: https://www.dasbiber.at/content/ich-wuerde-meinen-sohn-niemalsmohammed-nennen [November $11^{\text {th }}, 2017$ ].

Reynolds, Andrew: "Representation and Rights: The Impact of LGBT Legislators in Comparative Perspective” in: American Political Science Review 107, 2/2013:259-74, available here: https://doi.org/10.1017/S0003055413000051 [downloaded 2013].

Rosenberger, Sieglinde / Stöckl, Iris: "The Politics of Categorization - Political Representatives with Immigrant Background between 'the Other' and 'Standing For'” in: Politics, Groups, and Identities 6, 2/2018: 217-36, available here: https://doi.org/10. 1080/21565503.2016.1194764 [downloaded 2016].

Sauer, Birgit / Ajanovic, Edma: "Hegemonic Discourses of Difference and Inequality: Right-wing organisations in Austria" in: The Rise of the Far Right in Europe, Palgrave Macmillan, London 2016, 81-108, available here: https://doi.org/10.1057/978-1-13755679-0_4 [downloaded 2016].

Setzler, Mark / Yanus, Alixandra B.: "Why Did Women Vote for Donald Trump?" in: PS. Political Science \& Politics 51, 3/2018: 523-27, available here: https://doi.org/10.1017/ S1049096518000355 [downloaded 2018]. 
Wängnerud, Lena: "Women in Parliaments: Descriptive and Substantive Representation", Annual Review of Political Science 12, 2009, 51-69, available here: https://doi. org/10.1146/annurev.polisci.11.053106.123839 [downloaded 2009].

Wieshaider, Wolfgang: "Religious rules under Austrian State Law" in: Religious Rules, State Law, and Normative Pluralism - A Comparative Overview. Ius Comparatum Global Studies in Comparative Law 18, Springer, Cham 2016, 77-90, available here: https://doi.org/10.1007/978-3-319-28335-7_5 [downloaded 2016].

Astrid Mattes, Institute of Urban and Regional Research, Austrian Academy of Science, Postgasse7/4/2, 1010 Vienna, Austria, e - mail: astrid.mattes@oeaw.ac.at

Citation: Mattes- Astrid: "Liberal Democratic Representation and the Politicization of Religion", in: Appel, Kurt / Raschke, Carl (eds.): The Crisis of Representation (J-RaT 2018 / 2) pp. 142-171.

Datum der Publikation: 21.01.2019 